\title{
Studies on Serum Antitrypsin.
}

\author{
First Report. \\ Inhibition Mechanism of Serum against Tryptic Proteolysis.
}

By

\section{Mitsuhisa Hayakawa.}

(早川光久)

(From the Medical Clinic of Prof. T. Kurokawa, Faculty of

Medicine, Tohoku University, Sendai.)

(Received for publication, February 20, 1950)

The expression by Michaelis \& Menten ${ }^{1)}$ or that by Haldane ${ }^{2)}$ have hitherto been the favorites with many scholars who have made chemical kinetic studies of inhibition mechanism of enzyme action. Those expressions, however, are limited in their application only to certain special cases with many defects about themselves.

Recently a universally applicable theory was demonstrated by Goldtein, ${ }^{3)}$ the above expressions being therein comprised. Maruo, ${ }^{4}$ ' who also attained to the same equation of the first order inhibition as Goldstein's, further showed that it also could, under certain conditions, be introduced from the theory of adsorption where the reactions take place on the heterogeneous system. In this paper I intend to treat the inhibition mechanism of human blood serum under the substrate-trypsin-serum-system, chiefly following Goldstein's theory.

The Theory of Inhibition Mechanism.

On the assumption that a reversible enzyme inhibitor combination be brought forth, the relation between the enzyme (E) and the inhibitor (I) in the state of equilibrium may through the law of mass action, be expressed as follows;

$$
\mathrm{KI}_{\mathrm{I}}=\frac{\left(\mathrm{E}_{\mathrm{f}}\right)\left(\mathrm{I}_{\mathrm{f}}\right)}{(\mathrm{EI})} \text {. . . . . . . . . . . . . . . . . . }
$$

here $\left(E_{f}\right),\left(I_{f}\right)$ and $(E I)$ denoting molar concentrations of free enzyme, of free inhibitor and of the compound of the both respectively, and $\mathrm{K}_{\mathrm{I}}$ the dissociation constant.

As the reaction velocity at its beginning is proportional to the enzyme concentration, the inhibition coefficient $i$ which is obtained from the retardation of the reaction velocity must be given in this expression: 


$$
\mathrm{i}=1-\frac{\left(\mathrm{E}_{\mathrm{f}}\right)}{(\mathrm{E})}=\frac{\left(\mathrm{I}_{\mathrm{f}}\right)}{\left(\mathrm{I}_{\mathrm{f}}\right)-\mathrm{KI}_{\mathrm{I}}}
$$

This is the same as $M^{2}{ }^{4} 0^{4)}$ introduced. Now from expressions (1) and (2), we can get the expression (3) by eliminating $\left(E_{f}\right)$ and $\left(I_{f}\right)$,

$$
\begin{array}{r}
\left(E I=E-E_{f}=I-I_{f}, \quad E_{f}=\frac{K_{I}}{I_{\mathfrak{f}}-K_{I}} E\right): \\
I=K_{1} \frac{i}{1-i}+i E . . . .
\end{array}
$$

Then with the quantitative relation between $\mathrm{E}$ and $\mathrm{i}$ taken into account, we are to have the following three zones of enzyme behavior ${ }^{3)}$ ( $\Delta \mathrm{i}$ means the minimal value to be measured of the varying $i$ ).

i) Zone A, where all inhibitors are in a free state.

$$
\mathrm{E}<0,1 \quad \Delta \mathrm{i}, \mathrm{E}^{\prime}=\frac{\mathrm{E}}{\mathrm{KI}} . \quad \text {. . . } \quad \mathrm{I}=\mathrm{K}_{\mathrm{I}} \frac{\mathrm{i}}{1-\mathrm{i}} . \quad . \quad . .
$$

ii) Zone B, where expression (3) is generally applied.

$$
0.1 \Delta \mathrm{i}<\mathrm{E}^{\prime}<100 \Delta \mathrm{i}
$$

iii) Zone $\mathrm{C}$, where all inhibitors are in combined state.

$$
E^{\prime}>100 \Delta \mathrm{i} . . . \quad . \quad . \quad I=I E
$$

These theoretical equations hold good only when the amount of hydrolysis of the substrate is proportional to the concentration of the enzyme. Therefore, if the inhibition coefficient $i$ ', which has been obtained from the amount of hydrolysis of the substrate not in proportion to the concentration of the enzyme, should be applied, the three equations (3), (4) and (5) could not be directly satisfied. Accordingly, as is treated below in detail, a new equation must be found with regard to the value of $i^{\prime}$ by further studies of how it changes when in the trypsin-substrateserum-system the quantities of any two of the three are kept constant and only that of the other is varied.

\section{Experimental.}

Method.

Enzyme: Pancreatin (Iwaki); Substrate: casein (Hammarsten), both resolved in a m/15-phosphate-buffer solution $(\mathrm{pH} 8.0$ as the optimal $\mathrm{pH}$-value for tryptic proteolysis by pancreatin); Serum: diluted to a needed extent with saline buffer solution.

Incubation was conducted at $38^{\circ} \mathrm{C}$ under toluol and the acidity increased in 2 c.c. digestate $(0.01 \mathrm{n}-\mathrm{NaOH})$ was found by formol titration, which Northrop ${ }^{5)}$ had adopted. With a view to controlling I tried further experiments in incubation under the same conditions, in which at one 
time trypsin was used with or without serum and at another only serum was used. In these cases no substrate was added. The figures given in the table show the corrected values (average values from 3 experiments).

\section{Results.}

I. Cases where the concentration of the enzyme solution is varied.

a) When the concentration of the enzyme solution is made relatively low and so reaction conditions seem to be in zone $\mathrm{A}$ (provided $\Delta \mathrm{i}^{\prime}=0.05$, then $\left.\mathrm{E}^{\prime}<0.5 \Delta \mathrm{i}^{\prime}\right)$ :

In this case the amount of the hydrolysis by trypsin of the substrate $\mathrm{x}_{0}$ is not proportional directly to the enzyme concentration but to the square root of it, if the serum is not present. This proves that Schutz's rule is applicable to the relation between these two quantities.

\section{TABLE I-a.}

Experiment in which the Enzyme is Varied while the Plasma Kept Constant.

(1) Concentration of the Enzyme Relatively Low.

2.0 c.c. $2 \%$ casein +2.0 c.c. enzyme +0.5 c.c. plasma (1:40) 1.5 c.c. buffer or 2.0 c.c. buffer; $24 \mathrm{hrs}$.

\begin{tabular}{|c|c|c|c|c|c|c|}
\hline \multirow{2}{*}{$\begin{array}{c}\mathrm{E} \times 10^{4} \\
\text { Relat: } \\
\text { conc. } \\
\text { of enz. } \% .\end{array}$} & \multirow[t]{2}{*}{$\sqrt{E}$} & \multicolumn{2}{|c|}{$\begin{array}{l}\text { Acidity increas- } \\
\text { ed; c.c. } 0,01 \mathrm{n}- \\
\mathrm{NaOH}^{*}\end{array}$} & \multirow[t]{2}{*}{$\mathrm{E}_{\mathrm{f}}$} & \multicolumn{2}{|c|}{$\begin{array}{c}\text { Inhibition } \\
\text { coefficient }\end{array}$} \\
\hline & & $\mathbf{x}_{0}$ & $\mathbf{x}$ & & $\mathbf{i}$ & $i^{\prime}$ \\
\hline 0.04 & 20 & 3.77 & 3.02 & 14 & 0.965 & 0.200 \\
\hline 0.02 & 14 & 2.83 & 1.68 & 8 & 0.960 & 0.410 \\
\hline 0.01 & 10 & 2.35 & 0.76 & 3.5 & 0.965 & 0.675 \\
\hline 0.005 & 7 & 1.80 & 0.59 & 3 & 0.940 & 0.670 \\
\hline 0.0025 & 5 & 1.07 & 0.16 & 0.7 & 0.970 & 0.766 \\
\hline
\end{tabular}



Fig. 1. The amount of hydrolysis and the enzyme concentration. calculated from $k 0,181, \bullet$, observed; $37^{\circ} \mathrm{C}, 24 \mathrm{hrs}$; Increased acidity in 2 c.c. digestate., c.c. $0.01 \mathrm{n}-\mathrm{NaOH}$.

* $x_{0}=$ without plasma, $x=$ with plasma.

** calculated from $E_{f}=\frac{x}{k}$, by the aid of Schutz' rule. $\mathbf{k}=0.219$.

$* * * i=1-\frac{E_{f}}{E}, i^{\prime}=1-\frac{x}{x_{0}}$.

Accordingly $x_{0}-E$ curve describes a parabola of $1 / 2$ order (Fig. 2).

On the other hand, in presence of the serum the amount of hydrolysis $\mathbf{x}$ is in direct proportion to the enzyme concentration.

From these equations

$$
\mathrm{x}_{0}=\mathrm{K} \sqrt{\mathrm{E}} \text {. }
$$

and

$$
\mathrm{x}=\mathrm{K}^{\prime} \mathrm{E}
$$




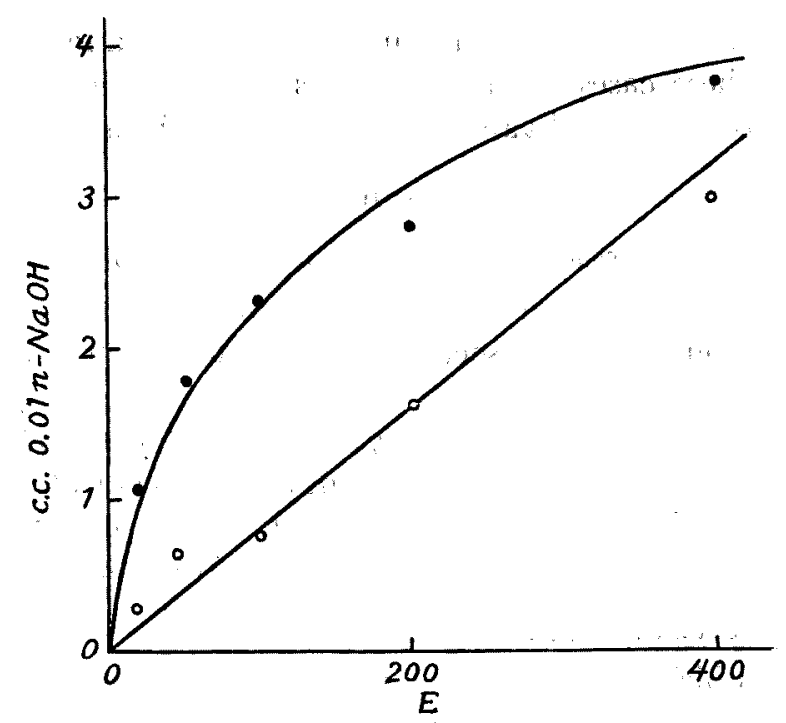

Fig. 2. The concentration of the enzyme is varied (Zone A). Values are tabulated in Table $\mathrm{I}-\mathrm{a} ; \bullet=$ without plasma, $\circ=$ with 0.5 c.c. plasma $(1: 40)$; $37^{\circ} \mathrm{C}, 24$ hrs. 0 c.c. $0.01 \mathrm{n}-\mathrm{NaOH}$.

must be concluded, provided that $\mathrm{K}$ and $\mathrm{K}^{\prime}$ are arbitrary constants. In these experiments the condition of the reaction is thought to be in zone $A$, so the value of $\left(I_{f}\right)$ may be regarded as approximately equal to that of (I).

From the expression (2) we can have

$$
\frac{E}{E_{\mathrm{f}}}=\frac{\mathrm{I}}{\mathrm{K}_{\mathrm{I}}}+1
$$

This together with expression (7)' allows us to express the relation between $E_{\mathrm{f}}$ and $\mathrm{x}$, in

$$
\frac{E_{f}}{x}=\frac{K_{I}}{\left(K_{I}+I\right) K^{\prime}}
$$

As (I) can be made constant in a series of experiments and $\mathrm{K}^{\prime}$ and $\mathrm{K}_{\mathrm{I}}$ are both arbitrary constants, when

$$
\begin{aligned}
& \frac{\mathrm{KI}_{\mathrm{I}}}{\left(\mathrm{K}_{\mathrm{I}}+\mathrm{I}\right) \mathrm{K}^{\prime}}=\mathrm{K}^{\prime \prime} \\
& \frac{\mathrm{E}_{f}}{\mathrm{x}}=\mathrm{K}^{\prime \prime} \text {. . . . . . . . . . . . . . . . . }
\end{aligned}
$$

This indicates that $\mathbf{x}$ is proportional to the concentration of the free enzyme $\left(E_{f}\right)$. Now provided $K=K^{\prime \prime}$ for simplification, we can obtain the value of $\left(E_{f}\right)$ by calculation, and in consequence the value of $i$, the inhibition coefficient which should be defined by the equation $i=1-\frac{E_{f}}{E}$. 
These values just mentioned are according to the computation found constant irrespective of the concentration of the enzyme (Table I), which is consistent with the theory given in the equation (4), i.e. the reaction conditions should be in zone $A$.

Similar experiments with serum albumin produce the same results (Table I-b).

TABLE I-b.

Experiments with Serum Albumin.

2.0 c.c. $2 \%$ casein +2.0 c.c. enzyme +2.0 c.c. $2 \%$ serum albumin (E. Merck)-buffer solution or 2.0 c.c. buffer; Control: without substrate, corrected values presented.

\begin{tabular}{|c|c|c|c|}
\hline \multirow{2}{*}{$\begin{array}{c}\mathrm{E} \times 10^{4} \\
\text { Relat. } \\
\text { conc. } \\
\text { of enz. } \% .\end{array}$} & \multicolumn{2}{|c|}{$\begin{array}{l}\text { Acidity in- } \\
\text { creased, c.c. } \\
0.01 \mathrm{n}-\mathrm{NaOH}\end{array}$} & \multirow{2}{*}{$\begin{array}{l}\text { Inhibition } \\
\text { coefficient } \\
\mathrm{i} * \%\end{array}$} \\
\hline & $x_{0}$ & $\mathbf{x}$ & \\
\hline 0.01 & 1.85 & 0.45 & 0.976 \\
\hline 0.00 & 1.49 & 0.22 & 0 \\
\hline 0.0025 & 0.94 & 0.20 & 0.952 \\
\hline 0.00125 & 0.64 & 0.17 & 0.930 \\
\hline
\end{tabular}

* $x_{0}=$ without albumin, $x=$ with albumin.

** calculated from $\mathbf{k}=0.191$.

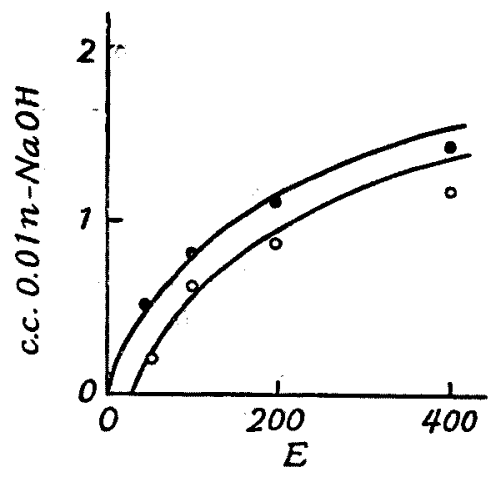

Fig. 3. The concentration of the enzyme is varied in zone $\mathrm{C}$; values are tabulated in Table II; $\bullet=$ without plas$\mathrm{ma}, 0=$ with 0.5 c.c. plasma $(1: 50) ; 37^{\circ} \mathrm{C}$, 3 hrs.; c.c. 0.01 n-NaOH.

b) When the reaction conditions seem to be in zone $\mathrm{C}$, enzyme solution of relatively high degree of concentration used $\left(E^{\prime}<500 \Delta \mathrm{i}^{\prime}\right)$.

The relation-curve between the amount of hydrolysis and the concentration of enzyme takes a shape like parabola, whether there is serum added or not (Fig. 3). In this case there exists an approximate coincidence between the two inhibition coefficients $i^{\prime}$ and $i$ which are obtained respectively from the retardation of the increase in acidity and from (E) and $\left(\mathrm{E}_{\S}\right)$ by the aid of Schutz's rule (Table II). This proves Schutz's rule to be applicable even to such a system with serum in zone C. But the results of these experiments can not always satisfy the equation (5), because it seems that the experimental errors have a great effect on one hand and parts of the reaction conditions lie perhaps in zone B on the other hand.

II. Cases in which the amount of the inhibitor is varied, with the concentration of the enzyme solution kept constant.

In these experiments I treated, for convenience sake only those whose reaction conditions are in zone $A$. As the results reveal, the degree of 
T.ABLE II.

Experiments in which the Enzyme Varied while the Plasma Kept Constant.

(2) Concentration of the enzyme relatively high.

4.0 c.c. $1 \%$ casein +2.0 c.c. enzyme +0.5 c.c. plasma $(1: 50)$ or 0.5 c.c. buffer; 3 hrs.

\begin{tabular}{|c|c|c|c|c|}
\hline \multirow{2}{*}{$\begin{array}{c}\mathrm{E} \\
\text { Relat. } \\
\text { conc. } \\
\text { of enz. }\end{array}$} & \multicolumn{2}{|c|}{$\begin{array}{l}\text { Acidity increas- } \\
\text { ed, c.c. } 0.01 \mathrm{n} \text { - } \\
\mathrm{NaOH}^{*}\end{array}$} & \multicolumn{2}{|c|}{$\begin{array}{l}\text { Inhibition } \\
\text { coefficient }\end{array}$} \\
\hline & $\mathbf{x}_{0}$ & $\mathbf{x}$ & $\mathrm{i}$ & $i^{\prime}$ \\
\hline 400 & 1.40 & 1.20 & 0.15 & 0.18 \\
\hline 200 & 1.16 & 0.85 & 0.27 & 0.20 \\
\hline 100 & 0.79 & 0.52 & 0.35 & 0.30 \\
\hline 50 & 0.49 & 0.19 & 0.64 & 0.63 \\
\hline
\end{tabular}

* $x_{0}=$ without serum, $x=$ with serum.

** calculated from $k=0.073$.
TABLE III.

Experiments in which the Plasma is Varied while the Enzyme

Kept Constant. (Zone A).

2.0 c.c. $2 \%$ casein +2.0 c.c. $0.01 \%$ enzyme $+(I)$ c.c. plasma (2-I) c.c. buffer; 24 hrs.

Acidity increased in 2 c.c. digestate; c.c., $0.01 \mathrm{n}-\mathrm{NaOH}$.

\begin{tabular}{|c|c|c|c|c|c|}
\hline \multirow{2}{*}{$\begin{array}{c}\mathbf{x}_{0} \\
\text { without } \\
\text { plasma }\end{array}$} & \multicolumn{5}{|c|}{$x$, with (I) c.c. plasma, (I) c.c. } \\
\hline & 0.2 & 0.5 & 1.0 & 1.5 & 2.0 \\
\hline 1.64 & 1.13 & 0.51 & 0.40 & 0.28 & 0.22 \\
\hline $\mathrm{i}^{\prime}=1-\frac{\mathrm{x}}{\mathrm{x}_{0}}$ & 0.31 & 0.69 & 0.76 & 0.83 & 0.87 \\
\hline$\frac{i^{\prime}}{1-i^{\prime}}$ & 0.45 & 2.25 & 3.15 & 4.9 & 6.7 \\
\hline
\end{tabular}

inhibition is not only in direct proportion to the concentration of the inhibitor, but the increasing rate of the value of inhibition coefficient $i^{\prime}$ (obtained from increased acidity) becomes the lower according as the concentration of the serum added becomes the smaller (Table III).

In order to inquire into this relation quantitatively I rewrite equation (3) as follows by the aid of equations (6) and (7) and eliminating $\left(E_{f}\right)$, which value can be found from equation (1),

$$
\frac{\mathrm{i}^{\prime}}{1-\mathrm{i}^{\prime}}=\frac{\mathrm{I}_{\mathrm{f}}}{\mathrm{KI} \sqrt{\mathrm{E}}}+\frac{1}{\sqrt{\mathrm{E}}}-1 \quad . \quad . \quad . \quad . \quad . \quad . \quad . \quad . \quad . \quad . \quad . .
$$

but $\mathrm{K}=\mathrm{K}^{\prime \prime}$ for simplification.

As in zone A (IE) is too small, in comparison with (I), to be negligible, $\left(I_{\boldsymbol{\xi}}\right)=(\mathrm{I})$ and the preceding expression can be

$$
\frac{\mathrm{i}^{\prime}}{1-\mathrm{i}^{\prime}}=\frac{\mathrm{I}}{\mathrm{KI} \sqrt{\mathrm{E}}}+\frac{1}{\sqrt{\mathrm{E}}}-1
$$

(E) can be made constant in a series of experiments, so a straight line must be drawn between the two values when $\frac{i^{\prime}}{1-i^{\prime}}$ is plotted on ordinate and $(I)$ abscissa. Figure shows that the results from Table VI are in exact accordance with the above theory when enzyme concentration is near $0.01 \%$. (Fig. 4). Similar experiments with serum albumin produce the same result (Fig. 5). Though the value of $(E)$ is to be determined only relatively, in case that of $\frac{1}{\sqrt{\mathbf{E}}}-1$ is small enough to be graphically neglected as above, equation (9) can be further simplified. 


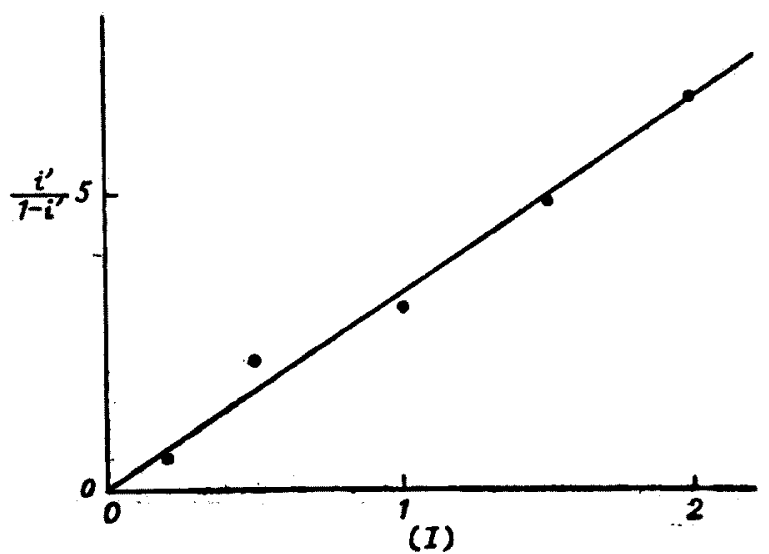

Fig. 4. The plasma is varied in zone A. Plotting $\frac{i^{\prime}}{1-i^{\prime}}$ against (I); Values are tabulated in Table III. observed, -, calculated from $\mathrm{K}_{\mathbf{l}}=0.3$, slope of the straight line.

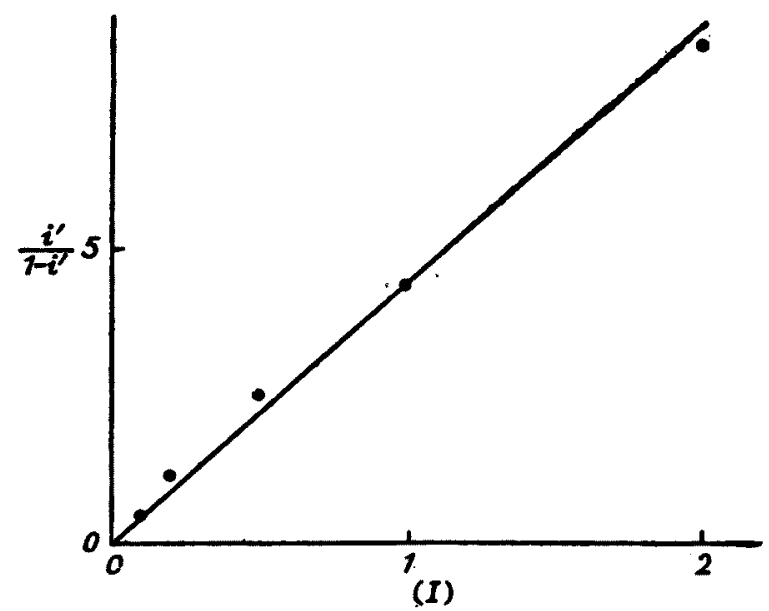

Fig. 5. Experiments with varying amount of serum albumin. 2.0 c.c. $2 \%$ casein +2.0 c.c. $0.01 \%$ enzyme+(I) c.c. $0.2 \%$ serum albumin $+2-(\mathrm{I})$ c.c. buffer; $37^{\circ} \mathrm{C}, 15 \mathrm{hrs}$., pH 8.0 ; formal-titration 2.0 c.c. digestate; $\bullet=o b-$ served, $-=$ calculated from $\mathrm{KI}=0.22$.

$\frac{\mathbf{i}^{\prime}}{1-\mathbf{i}^{\prime}}=\frac{\mathrm{I}}{\mathrm{KI}}$

Thus the value of $(I)$ as causing $1 / 2$ inhibition $\left(i^{\prime}=0.5\right)$ may give a relative value to $K_{\text {I. }}$ 
1II. Cases in which the concentration of the substrate is varied.

The value of inhibition coefficient $i^{\prime}$ is independent of the concentration of the substrate solution in both cases with serum and serum albumin.

\section{TAB LE IV.}

Experiments in which the Concentration of the Substrate Varied.

(1) Inhibitor: Plasma.

2.0 c.c. a $\%$ casein +2.0 c.c. $0.01 \%$ enzyme +0.5 c.c. plasma (1:40) 1.5 c.c. buffer or 2.0 c.c. buffer; 24 hrs.

\begin{tabular}{c|c|c|c}
\hline $\begin{array}{c}\text { Conc. } \\
\text { of Subst- } \\
\text { rate, \% }\end{array}$ & \multicolumn{2}{|c|}{ *Increased acidity } & $\begin{array}{c}\text { Inhibition } \\
\text { coefficient } \\
* *\end{array}$ \\
\hline 2 & $\mathrm{x}_{0}$ & $\mathrm{x}$ & \\
\hline 1 & 1.14 & 0.53 & 0.54 \\
0.5 & 0.65 & 0.30 & 0.54 \\
0.25 & 0.45 & 0.20 & 0.56 \\
0.125 & 0.17 & 0.08 & 0.53 \\
& 0.07 & 0.03 & -
\end{tabular}

* c.c. $0.01 \mathrm{n}-\mathrm{NaOH}, x_{0}=$ without plasma, $x=$ with plasma; mean value from 3 experiments.

$* * i^{\prime}=1-\frac{x}{x_{0}}$
TABLE V.

Experiments in which the Concentration of the Substrate is Varied.

(2) Inhibitor Serum Albumin.

2.0 c.c. a $\%$ casein +2.0 c.c. $0.04 \%$ enzyme +1.5 c.c. buffer +0.5 c.c. $2 \%$ serumalbumin or buffer; $20 \mathrm{hrs}$; Control: without substrate, corrected values presented.

\begin{tabular}{|c|c|c|c|}
\hline \multirow{2}{*}{$\begin{array}{l}\text { Conc. } \\
\text { of Subst- } \\
\text { rate, \% }\end{array}$} & \multicolumn{2}{|c|}{ *Increased acidity } & \multirow{2}{*}{$\begin{array}{l}\text { Inhibition } \\
\text { coefficient } \\
* \ldots\end{array}$} \\
\hline & $\mathrm{x}_{0}$ & $\mathbf{x}$ & \\
\hline 2 & 4.07 & 3.16 & 0.22 \\
\hline 1 & 2.37 & 1.85 & 0.22 \\
\hline 0.5 & 1.13 & 1.03 & 0.20 \\
\hline 0.25 & 0.65 & 0.54 & 0.17 \\
\hline 0.125 & 0.37 & 0.30 & 0.23 \\
\hline
\end{tabular}

*c.c., $0.01 \mathrm{n}-\mathrm{NaOH}, \mathrm{x}_{0}=$ without albumin, $\mathrm{x}=$ with albumin; $* * \mathrm{i}^{\prime}=1-\frac{\mathrm{x}}{\mathrm{x}_{\mathbf{0}}}$

The above results were the case with all experiments carried out with regard to the serum-albumin system.

\section{Discussion.}

In the competitive system ${ }^{3 \cdot 2}$ the value of inhibition coefficient $i$ should naturally be effected by the concentration of the substrate solution, for the former is a complex function of the latter. Therefore, Northrop ${ }^{6)}$ was in too haste when he concluded that there existed no compound of substrate with enzyme because the degree of inhibition might not be changed by the variation of substrate concentration. On the other hand, the classical theory that Michaelis and Menten ${ }^{11}$ held would ascribe this unchangeability of the value of $i$ to the fall of the splitting velocity of the substrate attacked by serum. But on such an occasion the value of inhibition coefficient can not be effected by the concentration of the enzyme, either. As a matter of fact, however, the result of my experiment was to the contrary.

Moreover, the result of my experiments coincides with the theoretical equation reached on the premise that one molecule trypsin combines re- 
versibly one molecule inhibitor in serum or in serum albumin according to the law of mass action. This fact proves that the assumed premise is correct. But we should make a mistake in thinking that the fact that there exists a stoichiometrical relation between enzyme and inhibitor affords a foundation for the denial of a compound of the both by adsorption. Furthermore, as the enzyme employed in my experiments seems to contain peptidase besides trypsin, those phenomena referred to above should be interpreted as the reactions that come in the enzyme complex system. Therefore, though I do not think that I have made clear the whole inhibition mechanism of serum against tryptic proteolysis by the above mentioned results of my experiments, I may be allowed to say that it has been brought out clearly on the part of the molecular kinetics relation.

And Goldstein's theory ${ }^{3)}$ holds good not only for the substrate-trypsinserum system, but in such cases where the amount of hydrolysis is not proportional to the concentration of enzyme. With respect to this relation I have succeeded in forming a theoretical expression.

\section{SUMMARY.}

Through my experiments no difference could be noticed between serum and serum albumin with regard to their inhibition mechanism.

1. No difference can be observed between serum and serum albumin with regard to their inhibition mechanism against proteolysis.

2. Goldstein's theory' is applicable to the substrate-trypsin-serum system, too.

3. In the inhibition of serum against tryptic proteolysis the reversible compound is formed, according to the law of mass action, between enzyme and inhibitor in serum.

4. I have built an equation representing these relations.

\section{References.}

1) Michaelis and Menten, Biochem. Ztschr., 1913, 49, 333.

2) Haldane, Biochem. Journ., 1915, 19, 338.

3) Straus and Goldstein, Journ. Gen. Physiol., 1943, 26, 559; 1944, 27, 529.

4) Maruo and Koga, Journ. Jap. Chem., 1949, 3, 25.

5) Northrop, Journ. Gen. Physiol., 1926, 9, 767; 1932/33, 16, 41.

6) Northrop, Journ. Gen. Physiol., 1922, 4, 487; 1923, 5, 335. 